\title{
Navigating Strategies and Metacognitive Awareness in Self-Regulated Mobile-Assisted Listening in a Second Language
}

\author{
Fidel Çakmak
}

\begin{abstract}
This study aimed to explore what navigating strategies L2 learners use during listening in a self-regulated mobile learning environment and whether or not metacognitive awareness about mobile-assisted listening correlated to text recall, incidental vocabulary learning and listening duration when learners regulated their listening. Learners with a low-level L2 proficiency were randomly assigned to an experimental group where they were allowed to control the listening process through audio control tools and a control group that was not allowed such control. Both groups listened to a 13.56-minute-long story on a mobile phone. Before listening, the Metacognitive Awareness Listening Questionnaire (MALQ) was administered. After listening, the participants were given a recall task and unannounced vocabulary tests. The results indicated that the participants who were allowed to regulate their listening preferred global and analytical listening strategies equally during the first listening while they tended to utilize analytical strategies during the second listening. The findings did not show any advantages of self-regulation for either text recall or incidental vocabulary learning. Finally, different patterns of relationships were observed between the learners' reported metacognitive strategy use and their recall and incidental vocabulary learning scores as well as the amount of time they spent on the listening task.
\end{abstract}

Article info

Keywords: L2 listening strategies, mobile-assisted L2 listening, metacognitive awareness, self-regulated L2 listening, incidental vocabulary learning

\section{Introduction}

Listening in a second language (L2) is an essential skill for L2 acquisition. This fundamental skill involves a complex process where listeners identify spoken text at phonological, lexical and propositional levels, and make meaning of the text by utilizing a variety of verbal and non-verbal cues (Hulstijn, 2003). Despite its immense importance, L2 listening is "the least researched of all four language skills" (Vandergrift, 2007, p. 191) and has received less research attention than other language skills (Rost, 2011; Vandergrift, 2004, 2007). Most of the L2 listening research has

Alanya Alaaddin Keykubat University, Department of Foreign Language Education, fidel.cakmak@alanya.edu.tr, ORCID:0000-0002-3285-7661 
focused on the outcome of listening as a product (Vandergrift, 2007); but how listeners interact with listening tasks has largely remained unexplored. With the advent of digital mobile technologies, mobile devices including mobile phones, tablets and PDAs provide innovative opportunities to practice and improve L2 listening skills through multimodal exposure to the spoken text whether inside or outside of the classroom setting and recently in social-network-based designs (Read et al., 2021). These learning environments encourage learners to adopt a more self-directed, autonomous approach to their own learning (Kukulska-Hulme, 2009; Luzon \& Gonzalez, 2006; Rahimi \& Katal, 2012) in that they can regulate the listening process when receiving aural input in real time. In this context, metacognitive knowledge about listening, which primarily involves planning how to listen (Field, 2008) also becomes crucial to fully exploiting a self-regulated listening environment.

Although digital mobile technologies are emerging strongly in the field of language learning, there is little research on how learners interact with the learning environment provided by these mobile technologies (Stockwell, 2008) and there is a need to observe how learners engage in mobile-assisted language learning (MALL) activities (Stockwell, 2013). Palalas (2011) mentioned the importance of observing language learners' "mobile habits" in regard to improving the design of the mobile assisted language learning (MALL) ecology (p. 79). MALL listening activities formed on the mobile habits could be exemplified as listening to podcasts, videos, music through websites or mobile applications on mobile devices such as tablets or mobile phones (Read et al., 2021). Burston $(2013,2014)$ pointed out that MALL implementations in language classes have been discussed for over the past 20 years and monitoring students' performance in MALL settings has been rare but is nonetheless essential for the effective exploitation of MALL. Read et al. (2021) also mentioned the necessity of research on the MALL effect on listening comprehension. There is no doubt that understanding how learners perceive, manage and control their listening on mobile devices can provide insights into the strategies employed during listening. Analysis of the navigational patterns exhibited by learners on mobile devices can reveal whether students make use of the platforms' flexibility in maximizing their own learning; and can indicate what kind of listening strategies they opt for in their autonomous, selfregulated listening (Desmarais et al., 1998). To date, few studies have utilized digital tracking systems to observe learners' interactions and involvement with a listening task by explicitly logging listening times, rehearsal times and navigation patterns (Cottam, 2010; Çakmak \& Erçetin, 2018; Hwang et al., 2014; Roussel, 2011; Stockwell, 2013). However, these studies are not followed by further studies to have a comprehensive understanding of metacognitive awareness makes a difference in L2 listening performance in mobile environments. Additionally, the issue of whether a learners' metacognitive awareness about listening is related to the learners' listening performance in a digital environment has not received much attention. The primary aim of the current study is to explore L2 learners' behavior when allowed to regulate their listening while listening to a narrative text on a mobile device with a view to making inferences about their listening strategies. A second aim of the study is to determine whether selfregulation during listening has an impact in L2 listening comprehension and incidental vocabulary learning. Finally, the study aims to explore whether a learners' metacognitive awareness about listening is related to their listening performance. 


\section{Self-Regulated Listening in Technology-Enhanced Language Learning Environments}

Technology has the potential to promote learner autonomy by providing different types of control to the learner such as pacing of the material, as well as the choice, order, and representation of content (Scheiter \& Gerjets, 2007). Navigational control during listening and built-in comprehension aids such as annotations, captions, subtitles, or guidelines for tasks may promote increased interest and motivation in learners (Alexander \& Jetton, 2003; Deimann \& Keller, 2006; Pardo-Ballester, 2012). These options can provide a flexible learning environment where learners' needs and learning styles can be accommodated (Deimann \& Keller, 2006; Plass et al., 1998; Plass \& Jones, 2005; Scheiter \& Gerjets, 2007). Such learning environments also allow learners to regulate their own learning.

Self-regulated listening refers to "the capacity of the listener to exercise physical control over the listening input by using a tool (Roussel, 2011, p. 98). In this context listeners control the audio content by tapping icons on the screen. This form of listening allows for tracking the listeners' cognitive behaviors which can be "an indicator of listeners' metacognitive ability to plan and regulate their own listening" (Roussel, 2011, p. 100). The nature of self-regulated listening affords an opportunity to listen to the text (Cárdenas-Claros \& Gruba, 2014) in a "personalized' way (Read \& Barcena, 2016, p. 112). Moreover, tracking the behavior of self-regulated listeners can provide insight as to their preferences with regards to speech rate (Robin, 2007; Zhao, 1997) and number of repeated exposures to a listening text (Oberg \& Daniels, 2013; Robin, 2007; Roussel, 2011). This self-regulated navigation of the text (Roussel \& Tricot, 2012) creates opportunities for learners to review the content of the text and helps them to reconstruct it (Matthews \& O'Toole, 2013) allowing the learner to compensate for an incomplete mental representation of the text (Read \& Barcena, 2016). Reviewing the content through navigational tools "allows listeners to become familiar with the content, vocabulary, and structure of the spoken text" (Vandergrift \& Goh, 2012 , p. 201) and to "verify the received information and focus on novel points in the text" (Alm, 2013, p. 268), all of which can "provide a more complete understanding of the content of the recording” (Read \& Barcena, 2016, p. 113).

Eliminating self-regulation in the form of a pre-set pace set by either the tape or the teacher may increase a student's level of anxiety during listening (Lavine, 1992). Jones (2002), in a qualitative study, observed that students were negatively biased towards the use of technology integration into L2 listening as a part of coursework when they were given no control over the technology. The students expressed that their needs were ignored, and that support and interaction in relation to the technology-based activities were not provided. Jones warns: "when students have little control over the listening comprehension technology, this increases the level of frustration and anxiety and can potentially hinder their learning" (p. 31). Pujolà (2002) investigated listening behaviors via a web-based multimedia program for self-study and the use of help options in five forms (dictionary, cultural notes, transcript/subtitles and rewind controls, feedback and consultation with experts) with 22 adult learners of Spanish. Her work concluded that glosses of all types were useful to learners with a low-proficiency level but were not exploited as frequently by more advanced learners. He observed a 
progression of behaviors that correlated with student proficiency. Specifically, lowproficiency learners compulsively used audio controls to rewind and replay text, intermediate proficiency learners made modest use of rewind to review selected portions of the text and high proficiency learners rarely used the rewind option.

Rivens-Mompean and Guichon (2009) explored learners' listening strategies while taking notes from video material. English as a foreign language (EFL) learner whose level of English ranked from beginner to advanced were asked to write down key words as they watched a two-minute video, type any notes online and then write a summary of the video document in an electronic notebook. They were provided listening aids such as access to an online dictionary and video control buttons allowing them to pause and rewind the video in order to facilitate the taking of notes while listening to the video file. The researchers identified three strategies based on the learners' actions as they watched the video: (a) global viewing: watching the report once or twice but never pausing; (b) split viewing: splitting the viewing of the document into shorter sections; (c) global and split viewing: first watching the report from the beginning until the end without any pauses and then a second viewing consisting of some pause and rewind operations. The researchers concluded that the most efficient strategies for clarifying comprehension consisted of either global or split viewing (a or b) as limited by the participants working memory. It is stated that navigating buttons such as pause, and rewind provide functionalities allowing the viewer to better manage long extracts. They concluded that the pattern of global viewing and split viewing paralleled what L2 learners could experience in the traditional classroom listening where a whole text is listened first and then followed by split listening for pointing out specific details in the text. They claimed that if the students are not trained to be aware of their listening strategies, they tend to repeat patterns similar to their experiences in the classroom.

Despite the positive benefits of self-regulated listening, research findings are inconclusive regarding the effects of such listening on incidental vocabulary learning, where learning takes place as a natural consequence of listening. As van Zeeland and Schmitt (2013) noted, listening received few outcomes in the area of incidental vocabulary acquisition and the volume of the research fell primarily into reading as a skill. They stated that this could have been due to the fact that vocabulary studies have been associated more frequently as acquisition from reading rather than listening and consequently the noted gains from reading have been better documented than those from listening (Brown et al., 2008; Vidal, 2011). The pioneering study on the vocabulary dimension in regard to listening was brought to the field by van Zeeland and Schmitt (2013). Although, the application in that study did not include mobile assisted selfregulated listening. In their study, they found that through listening, learners start gaining word knowledge in terms of both form and grammar recognition respectively prior to the form-meaning acquisition. However, they also noted that for listening to be beneficial for vocabulary gains required a frequency of occurrence of up to 15 for target words. When occurrence is lower than that, sustainable vocabulary learning is less likely to occur. 


\section{Metacognitive Awareness in Technology Enhanced L2 Listening Environments}

In recent years learners' metacognitive awareness has been a key issue in L2 listening strategy literature (Cao \& Lin, 2020; Fahim \& Fakhri Alamdari, 2014; Toapanta Túarez, 2019; Bozorgian \& Alamdari, 2018; Read \& Barcena, 2016; Tavakoli et al., 2012; Vandergrift et al., 2006). Metacognitive awareness in L2 listening can be referred as "understanding and awareness of the process involved in listening in another language" (Vandergrift et al. 2006, p. 432). Seeking a more in-depth understanding of L2 listening strategies, much of the current research focuses on how the availability and use of technology impacts learners as they progress from lower to higher proficiency and to what extent metacognitive skills impact L2 acquisition.

Studies on self-regulated listening suggest that learners employ a variety of strategies to deal with aural input depending on the complexity of the text and their proficiency in the L2. Current technologies make the interaction between the listener and the text observable by recording user behavior data such as mouse clicks, swipes, or taps on the screen. Through online tracking, researchers can explore how listeners engage with a text, including how much time they spent on tasks and how many times they repeated the text. Such data can provide valuable information about the listening processes and potentially the strategies utilized by the listener in an online learning habitat.

Cross (2014) reported on an exploratory case study with an advanced learner of English who was introduced to metatextual skills, specifically "the knowledge of the structural and functional features of texts and proceduralization of this knowledge for decision making, hypothesizing and strategic behavior for comprehension" (p. 10). This metacognitive instruction took place over nine weeks to promote her autonomous use of podcasts and improve her listening comprehension. The researcher noted that with appropriate guidance, the learner showed improvement in structuring her own listening practice autonomously. In this case, the participant eventually settled on a process that started with full listening twice, then listening to each problematic segment twice in turn, and then again listening to the full story to confirm her understanding. For her, this was an evolved process which started from global listening. The splitting of the text to confirm comprehension illustrates how the sequence of a listening task can be flexible to accommodate a learners' needs and concentrate their focus on the text. With guidance, the student progressed from a learning pattern that relied solely on the inclusion of notes to one incorporating a metacognitive strategy of manipulating the listening patterns of the podcast to improve her comprehension of the story.

In a similar vein, Fuente (2014) aimed to explore the effects of two modes of delivery: learner controlled, MALL and instructor manipulated language learning (IMLL) on intermediate L2 learners' noticing and two types of comprehension processing (top-down and bottom-up) of Spanish object pronouns during focus-on-form listening tasks. They found that the MALL group outperformed their counterparts in the noticing of target forms. As expected, the findings demonstrated a relationship between noticing and bottom-up comprehension processing but the relationship between noticing and top-down comprehension processing for the IMLL group was surprising. As presented in the think-aloud protocols, some learners of Spanish managed to answer the form-focused questions without reported noticing of specific information and 
furthermore, many of them processed input in a top-down manner in both the first and second listening. They then answered the specific bottom-up questions without using general content strategies such as inferencing. The researcher attributed the superiority of MALL group in noticing and comprehension in the aural input to their ability to manipulate input easily and to process it in a more effective way. Although the time on task was the same for both groups, learners in the MALL group did select the parts of input that would help them attain specific and general meaning in dialogues for the task completion. This selective listening facilitated the process of noticing which led to deeper processing and a link to activation of prior knowledge. Additionally, the thinkaloud protocols suggested a more efficient use of time and attentional resources in MALL group when compared to the IMLL group. When their listening strategies were analyzed: listeners in the MALL group listened once to some items and quickly moved on to subsequent ones; however, there were instances where they spent more time with some items repeating specific parts of the input. This likely had to do with the degree of difficulty of the tasks. The study concluded that self-regulated listening could help aural input processing and provide flexibility to better manage input processing.

By tracking listener's behaviors through a screen recorder, Roussel (2011) performed an online analysis of students' listening behaviors and their time spent on task to identify the listening patterns of listeners in a self-regulated system. The study consisted of four experiments; the first three of which investigated the effects on comprehension of listening conditions, the starting level of the learners' competence, and the learners' listening behaviors. The last one investigated the influence of particular language difficulties in German on comprehension and strategies, which will be excluded from this discussion. Roussel's results indicated that (1) self-regulated listening led to significantly better scores compared to listening once or twice; (2) no significant difference was observed between listening once or twice. Additionally, the learners' starting language levels affected their performance in comprehension whatever the listening conditions. Unsurprisingly, the learners with a better language level obtained the best score in comprehension in all of the listening conditions. The third experiment revealed different patterns of self-regulated listening: interrupted and uninterrupted, which indicate analytical and global listening, respectively. These two patterns exhibited various subsets: (1) Students listen to the text globally in the first listening and then start analytical listening in the second listening. This suggests that after gaining an overall impression, the students focused on specific textual elements to confirm, reject or clarify their comprehension. This first type of strategy was found to be effective, particularly for learners with a good initial competence. (2) Students listened to the text analytically followed by one or more globally listening repetitions. This strategy often resulted in poor comprehension due to difficulties with elements of the text. (3) Students listen to the text once or several times globally without any regulation. This occurred most frequently with bilingual or high proficiency learners and also with learners who had a lot of difficulties. This indicates that the lower proficiency listeners may not have been able to parse well enough to take advantage of the navigational tools. (4) Students listen to the text only once utilizing analytical listening but without any global listening. This strategy was used by listeners with poor initial level of English. As was highlighted clearly in the study, regardless of L2 learners' initial level, selfregulation provides an opportunity for learners to manage aural input; however, students 
benefit from being taught how to manage self-regulation and to make use of top down compensatory and metacognitive strategies to make meaning.

\section{The Present Study}

Research on how metacognitive listening awareness can be compared with listening performance and incidental vocabulary gains in a mobile environment is rather scarce. This kind of observation can give a fuller perspective of how listeners regulate their listening including their metacognitive awareness when engaged in L2 listening in a flexible listening environment. It is not clear whether comprehension and incidental vocabulary learning are facilitated if learners are allowed to control the aural input by pausing, forwarding or rewinding the text. The current study aims to contribute to the field by addressing the following research questions:

1. What listening behaviors do L2 learners exhibit during listening in a MALL environment when they are allowed to control the listening process?

2. Does self-regulation during listening affect listening comprehension, incidental vocabulary learning, and the amount of time spent on the task?

3. Is metacognitive awareness about listening related to text recall and incidental vocabulary learning for learners allowed to regulate their listening compared to those who were not allowed to regulate listening?

\section{Method}

\section{Participants}

The participants were 47 freshmen students with Turkish as L1 studying at a state university in Turkey in the program for Public Administration Management. The selection of the sample of individuals was random. There were 151 students registered for the course in the program in two sections. The researcher assigned each student a number and then used a table of numbers to select 50 students to be included in the sample. Three students did not want to take part in the study. The other students signed the consent forms before the intervention. All the students had completed one year of English Language Preparatory Program before enrolling in the program and they were required to take General English for four hours per week as a compulsory departmental elective in their first year in the program. Based on the scores on the Oxford Placement Test (Allen, 1992) employed before the treatment, the participants were classified as lower elementary-limited users (Common European Framework of Reference for Languages/A2 Waystage).

\section{Research design}

The participants were randomly assigned to an experimental $(n=24)$ or a control $(n=$ 23) group. In both groups, they were asked to listen to a slow-paced 13.56-minute-long story called The Judge sourced from the website of Voice of America, an official American broadcast geared towards non-native speakers, embedded in the application. 
The text chosen was appropriate to the level of the students in terms of vocabulary coverage. To provide a basis for metrics of this text, word frequency analysis was computed by the software Lextutor (https://www.lextutor.ca). The vocabulary profile established that the text had 253 Families, 326 Types and 1300 Tokens. $90.53 \%$ of the words in the text was in the range of K1 Words (1-1000, the most-used words) and 4.25 $\%$ was K2 Words (1001-2000, most-used words). In the experimental condition, the participants could regulate the listening task through audio control buttons. In the control condition, they were not given access to the audio control tools; they could only stop or repeat the audio file once. Both groups were allowed to listen to the story twice.

\section{Application}

A mobile assisted listening application was developed and optimized for Samsung Galaxy Mini GT-S5570 devices. The application connected to a web service that was developed with PHP language, MySQL database and JSON data interchange standard, and downloaded the experimental materials for each condition. Keystrokes were synchronously recorded and sent to the web service to be included in the online database. With the help of a web dashboard written with HTML and PHP languages, the researchers could alter system settings, activate the conditions before the experiment started and terminate them when the experiment was over. Experimenters could also monitor and download the participants' data as spreadsheets including their names, the treatment condition, and total time spent on the task.

\section{Instruments}

Both online data through keystrokes and offline data through printed instruments were collected.

\section{Keystrokes}

Participants' keystrokes on screen as they listened to the story with mobile phones were tracked online. Keystrokes were coded as follows:

- Lookword - word and time indication in millisecond when participants looked up a word while listening

- Change time - time indication for rewinding and forwarding

- Sound complete - indication for listening once from the beginning until the end

- Pause, play, stop, replay and finish were kept as log files which provided entries that contained data about how the participants interacted with the system as they listened.

The researcher had to read the datasheet in excel format to analyze how students listened to the text quantitatively. The offline data included a free recall task that the participants completed after listening to the story as a measure of students' listening comprehension as well as three unannounced vocabulary measures which aimed to assess form and meaning aspects of target words. 
Two sets of offline data collection instruments were used. The first offline set was used to control possible confounding factors and included the placement test and pretest. The aforementioned placement test was administered three months before the treatment. The pretest followed two weeks later and included 25 sentences in L2 which incorporated the target words of the text. The students were instructed to write L1 translation of these sentences. The second offline set included the instruments that were used to answer the research questions, which included a free recall task and four vocabulary tests that were administered immediately after the treatment as well as the Metacognitive Awareness Listening Questionnaire (MALQ).

\section{Free Recall}

Students were asked to listen to a recording and then transcribe as much as possible of the text into their native language, Turkish. Their performance on the recall task was evaluated based on phonetic parcel units, following the protocol of Johnson (1970). Specifically, the text was divided into linguistically coherent phonetic parcels according to natural pauses where a reader/narrator would take a breath to emphasize the text. A total of 365 phonetic parcel units were identified. Each parcel unit counted as a point and the max score was 365 . The segmenting of the protocols into phonetic parcel units was scored independently by two raters; the parcel units were then compared to establish inter-rater reliability. The inter-rater reliability of the written recall protocol is 0.93. Any discrepancies were resolved in meetings between the raters.

\section{Vocabulary Measures}

Three vocabulary measures were utilized directly upon the treatment to assess form and meaning comprehension aspects of target words, specifically: form recognition, L2 meaning production and L1 meaning production. These tests are regarded as direct tests that can demonstrate a learner's understanding of target words or production capacity for the target forms to give meaning either in L1 or L2 (Laufer and Goldstein, 2004; Waring and Takaki, 2003). To identify which words were to be selected as target words, the frequency of the words was checked through the Corpus of Contemporary American English (COCA). Twenty-five words with the highest frequency were listed as target words to be assessed after the treatment. The occurrence frequency range of the target words varied between 55,857 and 5,031 at the time of treatment. The 25 target words consisted of twelve verbs, ten nouns, and three were adjectives.

The form recognition test (Cronbach's alpha $=.871$ ) consisted of a checklist that included the 25 target words in L2 and 29 distractors. For each target word, participants were aurally asked to listen to a set of three words. Participants were then asked to select words from a list that they had heard in the story. For example:
(1) Fence
Land
Trap 
The L2 meaning production test with 25 items (Cronbach's alpha $=.789$ ) required the participants to note the L2 equivalent of the target words provided in L1. This task assesses productive knowledge of meaning and form (Webb, 2005). For example, in (2), the Turkish word "kumaş" is given and the learner is expected to write "cloth".

\section{(2) Kumaş}

The L1 meaning production test (Cronbach's alpha $=.807$ ) required the participants to translate L1 target words order to assess their receptive knowledge of meaning and form (Webb 2005). In (3), the learner is expected to recognize a target word and write its equivalent in Turkish. For example, "fisıldamak" is the Turkish equivalent of the target word "whisper".

(3) Whisper (v)

Although both L2 and L1 meaning production tests can assess knowledge of vocabulary form and meaning, they do so differently. The L2 meaning production test involved progressing from word form to word meaning, while the L1 meaning production test inverted the process moving from word meaning to word form (Nation, 2001). While the receptive recall is notably easier than productive recall (Nation, 2001), the current study minimized contaminating effects by administering the recall production tests prior to the recognition tests. In each test, correct answers were scored as 1 and incomplete or wrong answers were scored as 0 .

\section{Metacognitive Awareness Questionnaire (MALQ)}

The MALQ was designed by Vandergrift et al. (2006) to measure learners' awareness of L2 listening processes and their use of L2 listening. It serves as a tool to reveal to what extent individuals are aware of their listening processes and of their management of the aural input at a cognitive level. It is found to be both reliable and unidimensional (Ehrich \& Henderson, 2018). More explicitly, it was developed and validated for “assessing L2 learners' metacognitive awareness at any point in time of their language development. It can track their metacognitive development in L2 listening at different points of their language learning process, and guide learners to reflect on their own use of strategies and personal knowledge" (Vandergrift et al. 2006, p. 431). The questionnaire is composed of 21 items in five categories: problem-solving strategies (making and monitoring inferences), planning and evaluation strategies (preparing for listening and evaluating results of listening efforts), mental translation strategies (finding equivalents in the learners' own language), personal knowledge (perceptions of challenges, anxiety, and self-efficacy) and directed attention strategies (concentrating and staying on task). Each item of the questionnaire is responded to on a six-point Likert scale rating from 1 (strongly disagree) to 6 (strongly agree). 


\section{Procedures}

The data collection instruments were piloted with 6 students who had a similar level of language proficiency to that of the test group. Three students were assigned for each condition. The pilot group tested the entire protocol. Revisions regarding the instructions, test items and the time allowed for the tests were incorporated based on the pilot data. For the experiment, a laboratory composed of two classrooms was set up with a router in each classroom in order to allow the participants to connect to the Internet and run the listening application. The conditions were administered at different times to avoid any communication between the experimental groups. Screencasts with a different listening text and glosses were shown to the participants in each condition prior to treatment so that they could have a better understanding of what to expect during the application. Given no specific instructions about the vocabulary tests prior to the treatment, the students were told only that they were going to listen to a story through mobile phone by using the application and then would be asked to write down what they remembered from the text. During the treatment, all keystrokes were recorded to the online database as they listened to the text. The students were requested to use earphones to minimize distraction. The listening span was also recorded online to examine how long it took the participants to complete the listening task. The offline data collection was subsequently conducted through pen and paper activities. Following the listening task these activities were presented in a fixed order to minimize the possibility of learning the meaning of a given word from the previous test. As the tests aimed to measure incidental vocabulary learning, they were administered unannounced. Approximately 80 minutes was allotted for data collection per condition. As for the MALQ, it was administered in English after the treatment in written form. Participants required approximately 20 minutes to complete it. MALQ scores were obtained to identify the existing metacognitive awareness of the participants at the time of treatment so as to relate their measured listening awareness in the five categories and their actual listening performance as assessed by scores obtained from recall, vocabulary tests and listening duration.

\section{Results}

The online data from the experimental group was the basis for the investigation of the participants' interaction with the audio file during listening. Their behavior was coded as global, analytical, or segmented listening (see Table 1). Global listening refers to listening to a text from the beginning to the end without any interruptions. Analytical listening, on the other hand, involves listening to the text with more than one or two interruptions (Roussel, 2011, pp.107-108). Segmented listening involves truncated listening where the student does not listen through to the end of the text. Table 1 indicates that there were an equal number of participants who preferred global or analytical approaches in the first listening. In the second listening, the participants primarily opted for analytical listening. 


\section{Table 1}

Frequency of Listening Strategies

\begin{tabular}{lcccc}
\hline & \multicolumn{2}{c}{$\mathbf{1}^{\text {st }}$ Listening } & \multicolumn{2}{c}{$\mathbf{2}^{\text {nd }}$ Listening } \\
\hline Global & $\boldsymbol{f}$ & $\%$ & $\boldsymbol{f}$ & 8.34 \\
Analytical & 11 & 45.83 & 2 & 75.00 \\
Segmented & 11 & 45.83 & 18 & 8.34 \\
No listening & 2 & 8.34 & 2 & 8.34 \\
Total & 0 & 0.00 & 2 & 100 \\
\hline
\end{tabular}

An examination of the combination of strategies in first and second listening showed that an equal number of students preferred to listen globally first and then analytically $(n=9)$ or to listen analytically in both the first and second listening $(n=9)$. Only two students preferred to listen globally in both instances. Overall, the data suggests that an analytical listening approach was more prevalent than global listening.

Table 2 provides descriptive statistics on text recall and incidental vocabulary learning. The data for two students in the experimental group and one student in the control group were not included in the analyses since their performance measures were incomplete. Thus, these analyses were conducted based on data from 22 students. The recall scores were compared through an independent samples t-test which revealed that the groups did not differ in terms of text recall, $\mathrm{t}_{42}=1.23, p>.05^{2}$. A one-way MANOVA on a linear combination of vocabulary measures yielded a nonsignificant difference between the groups (Wilks' lambda $=.925, p>.05)^{3}$. As such the results suggest that self-regulation during listening does not facilitate either text recall or incidental vocabulary learning.

\section{Table 2}

Descriptive Statistics for Text Recall and Incidental Vocabulary Learning

\begin{tabular}{lcccc}
\hline & \multicolumn{2}{c}{ Experimental } & \multicolumn{2}{c}{ Control } \\
& Mean & SD & Mean & SD \\
\hline Text recall & 12.32 & 7.73 & 9.50 & 7.46 \\
Vocabulary measures & & & & \\
$\quad$ Form recognition & 8.82 & 3.35 & 10.55 & 3.25 \\
L2 meaning production & 10.18 & 4.03 & 10.77 & 3.98 \\
L1 meaning production & 12.77 & 4.09 & 14.50 & 3.99 \\
\hline
\end{tabular}

Table 3 provides the amount of time the groups spent on the listening task during the first and second listening as well as the total time on task. The experimental group in self-regulation mode spent a significantly longer time on the listening task during the first listening, $t_{42}=3.22, p<.05$ than the control group (CG) in no self-

\footnotetext{
2 The assumption of homogeneity of variances was sustained.

${ }^{3}$ The assumptions of homogeneity of variance-covariance matrices were sustained.
} 
regulation mode. However, the difference between the groups was not statistically significant either in terms the second listening, $t_{42}=1.06, p>.05$ or the total amount of time spent on the task, $t_{42}=1.74, p>0.5$. The mode did not make any statistically significant difference in the total amount of time spent on the task.

Table 3

Descriptive Statistics for Time-on-Task

\begin{tabular}{llccc}
\hline & \multicolumn{2}{c}{ Control Group } & \multicolumn{2}{c}{$\begin{array}{c}\text { Experimental Group } \\
\text { (self-regulation mode) }\end{array}$} \\
& Mean & SD & M & SD \\
\hline 1st Listening & $0: 14: 53$ & $0: 00: 35$ & $0: 18: 49$ & $0: 05: 41$ \\
2nd Listening & $0: 13: 05$ & $0: 02: 59$ & $0: 11: 33$ & $0: 06: 05$ \\
Total duration & $0: 27: 59$ & $0: 03: 16$ & $0: 30: 23$ & $0: 05: 34$ \\
\hline
\end{tabular}

Table 4 provides the correlations of MALQ scales with text recall, vocabulary performance as determined by the sum of all vocabulary measures and listening duration for the no self-regulation and self-regulation groups separately. These correlations show that when learners are not allowed to control the listening process, participants' awareness of directed attention is positively correlated to listening duration. Additionally, reported awareness of directed attention also facilitates text recall. On the other hand, a different picture is observed when learners are allowed to control the listening process. In this condition a negative correlation exists between listening duration and reported awareness of directed attention as well as between recall and awareness of problem solving.

\section{Table 4}

Correlations of the MALQ Scales with the Performance Measures

\begin{tabular}{|c|c|c|c|c|}
\hline Group & MALQ Scales & Vocabulary & Recall & Listening duration \\
\hline \multirow{5}{*}{ 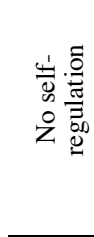 } & Planning and Evaluation & -.220 & -.150 & .152 \\
\hline & Directed Attention & .264 & $.514^{*}$ & $.444 *$ \\
\hline & Person Knowledge & .005 & .226 & .061 \\
\hline & Mental Translation & -.092 & .124 & -.184 \\
\hline & Problem Solving & .006 & -.041 & .136 \\
\hline \multirow{5}{*}{ 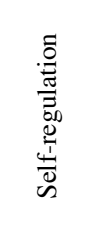 } & Planning and Evaluation & .114 & .019 & -.158 \\
\hline & Directed Attention & .031 & .108 & $-.440 *$ \\
\hline & Person Knowledge & -.197 & .135 & .006 \\
\hline & Mental Translation & -.067 & -.099 & .056 \\
\hline & Problem Solving & -.051 & $-.428 *$ & -.010 \\
\hline
\end{tabular}




\begin{abstract}
Discussion
The findings indicate that an analytical listening approach is preferred over global listening when learners are allowed to control their listening process. This may suggest that lower proficiency learners process the text in smaller units and might have taken more time to construct meaning (at least in the first listening). It should be noted that some of the students listened globally in the first listening and then switched to analytical listening when listening for the second time. Roussel (2011) argues that this may be indicative of learners' planning and monitoring strategies suggesting that they focus on the textual elements to confirm, reject or clarify their comprehension after gaining an overall impression through global listening. The fact that the experimental group regulating their listening spent more time on the task during the first listening might indicate that they were engaged with using this technical opportunity to help improve their comprehension when first exposed to the text. However, with regards to the second listening and the total amount of time spent on task, there was no significant difference between groups. Presumably, there would be little reason to slow down the second listening. Those who understood the text might even cut short the second listening bringing the overall time on task down to match the control group which had no option on the speed of the second listening. This suggests that the time spent on a second listening opportunity and the total time spent on task are not strictly correlated to the control options available to the listener.

The findings based on offline measures do not provide any evidence in favor of learner control. Specifically, the participants who were allowed to regulate their listening did not have significantly higher means than those who were not in terms of either text recall or vocabulary learning. This is surprising since a distinctive feature of mobile devices is to provide learners with control over the input (Fuente, 2014). Such control is supposed to support learners in noticing and directing their attention towards a certain form and, in turn, facilitate learning in a range of contexts (Kukulska-Hulme \& Bull, 2009). Roussel (2011) also speculated that giving learners an opportunity to have control (self-regulation) over input improves the participants' information processing and "allows them to better handle incoming aural discourse" (p. 114). However, the findings of her study, similar to those of the current study, indicated that self-regulation did not enhance low proficiency learners' performance and so the degree to which selfregulating strategies improve listening performance of learners may depend more on the learner's level of language proficiency. Regardless of whether or not learners are provided with flexibility to regulate their listening, their level of proficiency demonstrates a greater effect on comprehension than the availability of audio controls. As such, these findings present a potential challenge to the view that technology alone is sufficient to support autonomous learning.

Another finding of the current study is that learners' awareness of directed attention (i.e. concentrating on the task) is positively related to improved comprehension and listening duration when no self-regulation of the text is available. It could be expected that, when learners, particularly low proficiency learners, are provided with no self-regulation mechanism for their listening, they would use directed attention as a primary strategy to improve their comprehension. Presumably in this condition they would feel the need to concentrate hard on the input. The observed positive relationship
\end{abstract}


between directed attention and listening performance has been shown in previous research as well (e.g., Al-Alwan et al., 2013; Li, 2013; Tavakoli et al. 2012). The correlation between directed attention and time spent on the task may suggest that constructing meaning through an inflexible environment can take more time because students, especially low-level students, labor on textual elements to construct meaning more than using compensatory resources or extra-textual elements such as the use of background knowledge. This forced focus on task might very well help them to recall the text better due to enhanced attention to the task.

On the other hand, when learners are allowed to control the listening process, a negative relationship exists between listening duration and awareness of directed attention as well as between recall and awareness of problem-solving. This group did not listen to the text continuously from beginning to the end but was able pause and replay at any time. Such technical flexibility can enable listeners concentrate on various parts of the text in order to use new information to confirm their understanding. For instance, listeners may miss some points or not have understood something, but then might focus on the other more comprehensible incoming parts to compensate for the gaps and infer the meaning of the parts they found confusing, resulting in less time spent on task. The negative correlation between the use of problem-solving strategies and recall of the text is surprising for this group since previous research (e.g., Al-Alwan et al., 2013) has shown that problem-solving facilitates performance. It might be that when listeners are in search of a solution to redress a comprehension failure, they are doing more problem solving than listening, leaving them unable to construct the whole meaning of the text and also with an impaired recall of the text in general. Also, it should be noted that the self-regulation here was limited to audio control. There was no option to look at the transcript, which is provided on the Voice of America (https://learningenglish.voanews.com) and would therefore be considered an authentic complementary gloss to listening in this context. These findings contradict with previous studies (Chang \& Chang, 2014; Lai \& Gu, 2011) showing that students given technical autonomy to learn at their own pace are presumably able to deploy their listening strategies in a flexible way, which could enable them to be conscious of what they have listened to and also to monitor their own progress with the use of their preferred strategy.

\section{Conclusion}

This study aimed to explore the listening strategies of EFL learners with low-level language proficiency in a mobile environment. The findings demonstrated the learners' preferences and their listening behaviors when listening to the text on a mobile platform whether or not self-regulation was provided. The researchers assumed that given the flexibility of navigating their listening, L2 listeners would interact differently with the content provided through mobile platform. However, the results show that to some extent when given control over pace, the listeners worked on the text more in the first exposure to the script than in the second exposure. However, the flexibility in control did not improve their listening comprehension and incidental vocabulary learning. The findings highlight the association of listening processes and reported listening strategies. Analytic listening might reflect bottom-up listening strategies while global listening 
might be more indicative of top-down strategies. Although learner control over the pace of listening might lower anxiety with listening in the L2, it may not necessarily promote interactive use of both top-down and bottom-up strategies. As an implication of this study, we can say that explicitly teaching a metacognitive strategy and the benefits of using a combination of strategies and metacognitive instruction could be a resolution for achieving more successful listening comprehension (Bozorgian \& Fakhri Alamdari, 2018; Fahim \& Fakhri Alamdari, 2014; Blanco \& Guisado, 2012; Ngo, 2015; Rost, 1994; Vandergrift, 1998, 2007; Vogely, 1995).

Strategy instruction could enable listeners who over-rely on only bottom-up or top-down strategies to employ a combination of various strategies for improved comprehension. This knowledge could, in turn, increase the learners' motivation, selfconfidence and the general feeling of control over listening (Yeldham \& Gruba, 2016). Through such strategy training, listeners could develop a strategic approach to listening and also develop a better awareness of using integrated strategies to improve listening comprehension (Cao \& Lin, 2020; Toapanda Túarez, 2018) and help them handle the fluctuations in the listening performance (Fahim \& Fakhri Alamdari, 2014). It is clearly not learner autonomy in and of itself that makes a positive difference in performance. But rather, the combination of strategy training and a teacher's feedback on their strategy use intertwined with learner technology control that can facilitate more effective autonomous mobile/computer assisted learning (Bozorgian \& Alamdari, 2018; Jones, 2002; Zou, 2013). It is advisable then to design listening tasks with a holistic view of listening along with a teacher's pedagogical guidance, and metacognitive strategy training to make mobile-assisted L2 listening a more effective and successful learning tool. This study concurs with the study by Read and Barcela (2016) in regard to the needs of students (specifically lower-level students) to be more attentive to strategies recommended in the app so as to better manage their listening problems or difficulties. Overt development of this awareness is feasible through instruction and the application of a holistic view of listening processes in MALL conditions. Further studies could be designed to investigate if metacognitive strategy training makes any differences in technically different modes (no self-regulation and self-regulation) on L2 listening comprehension incidental vocabulary learning in a mobile environment.

There are a few limitations in this study. Firstly, the study includes a relatively small sample size. Secondly, a survey of learning styles was not applied, which could have given an idea of the students' learning styles. This could help elucidate why certain students prefer analytical or global or segmented listening. Such information could help a researcher to generalize students' general tendencies in listening on a mobile platform more accurately. Future research could be designed to reveal students' learning outcomes from strategy training for using a mobile platform.

\section{Acknowledgement}

This research received no specific grant funding from any agency in the public, commercial, or non- profit sectors. The author also expresses her heartfelt thanks to Madlen Kamhi for always being there and ready to offer her encouragement as well as mobile equipment and travel grants to conduct the current research. 


\section{Statements on Open Data, Ethics and Conflict of Interest}

The present study was part of a larger study conducted for the author's PhD. Dissertation (Çakmak, 2014). This study was partially presented at the XIXth International CALL Research Conference in Bruges in 2018 and published online in the Proceedings of CALL2018 Conference (Çakmak \& Erçetin, 2018). The data used in this research contain assessment scores. We are, therefore, unable to make this data publicly available. The participants' personal information was kept and protected during the research process. The participation was voluntary, and the consent forms were obtained. We declare that no conflict of interest exists in the work reported above.

\section{References}

Al-Alwan, A., Asassfeh, S., \& Al-Shboul, Y. (2013). EFL learners' listening comprehension and awareness of metacognitive strategies: How are they related? International Education Studies, 6(9), 31-39. http://doi.org/10.5539/ies.v6n9p31

Alexander, P.A., \& Jetton, T. L. (2003). Learning from traditional and alternative texts: New conceptualization for an information age. In A. C. Graesser, M. A. Gernsbacher, \& S. R. Goldman (Eds.), Handbook of discourse processes (pp. 199-241). Erlbaum. https://doi.org/10.1007/987-1-4419-5546-3

Allen, D. (1992). Oxford placement test 2 (New edition). Oxford University Press.

Alm, A. (2013). Extensive listening 2.0 with foreign language podcasts. Innovation in Language Learning and Teaching, 7(3), 266-280. https://doi.org/10.1080/17501229.2013.836207

Bozorgian, H., \& Fakhri Alamdari, E. (2018). Multimedia listening comprehension: Metacognitive instruction or metacognitive instruction through dialogic interaction. ReCALL, 30(1), 131-152. doi.org/10.1017/S0958344016000240

Blanco, M., \& Guisado, J. J. (2012). Exploring the listening process to inform the development of strategy awareness-raising materials. The Language Learning Journal, 40(2), 223-236. https://doi.org/10.1080/09571736.2011.621548

Brown, R., Waring, R., \& Donkaewbua, S. (2008). Incidental vocabulary acquisition from reading, reading-while-listening, and listening to stories. Reading in a Foreign Language, 20, 136-163. https://files.eric.ed.gov/fulltext/EJ815119.pdf

Burston, J. (2013). Mobile-assisted language learning: A selected annotated bibliography of implementation studies 1994-2012. Language Learning and Technology, 17(3), 157-225. http://dx.doi.org/10125/44344

Burston, Jack. (2014). The reality of MALL: Still on the fringes. CALICO Journal, 31, 103-125. http://doi.org/10.11139/cj.31.1.103-125

Cao, Z., \& Lin, Y. (2020). A study on metacognitive strategy use in listening comprehension by vocational college students. English Language Teaching, 13(4), 127-139. https://doi.org/10.5539/elt.v13n4p127

Cardenas-Claros, M. S., \& Gruba, P. A. (2014). Listening interactions with help options in CALL. Computer Assisted Language Learning, 27(3), 228-245. https://doi.org/10.1080/09588221.2012.724425 
Chang, C., \& Chang, C-K. (2014). Developing students' listening metacognitive strategies using online videotext self-dictation-generation learning activity. The EuroCALL Review, 22(1). http://dx.doi.org/10.3390/languages5020021

Cottam, M. (2010). The effects of visual and textual annotations on Spanish listening comprehension, vocabulary acquisition and cognitive load. Unpublished doctoral dissertation. Arizona State University.

Cross, J. (2014). Promoting autonomous listening to podcasts: A case study. Language Teaching Research, 18(1), 8-32. https://doi.org/10.1177/1362168813505394

Çakmak, F. (2014). Exploring the role of multimedia glosses and strategy use in second language listening comprehension and incidental vocabulary learning in a mobile environment. Unpublished doctoral dissertation. Boğaziçi University.

Çakmak, F., \& Erçetin, G. (2018). Effects of gloss type on text recall and incidental vocabulary learning in mobile-assisted L2 listening. ReCALL, 30(1), 24. https://doi.org/10.1017/S0958344017000155

Çakmak, F., \& Erçetin, G. (2018). Metacognitive awareness about listening in selfregulated L2 listening in a mobile environment. In J. Colpaert, A. Aerts \& F. Cornillie (Eds.), Call your data: Proceedings (pp. 92-100). University of Antwerp. https://www.call2018.org/wp-content/uploads/2018/07/proceedingsCALL-2018.pdf

Deimann, M., \& Keller, J. M. (2006). Volitional aspects of multimedia learning. Journal of Educational Multimedia and Hypermedia, 15(2), 137-158. https://www.learntechlib.org/primary/p/6140/.

Desmarais, L., Laurier, M., \& Renie, D. (1998). The analysis of navigation patterns in CALL. Computer Assisted Language Learning, 11(3), 309-315. https://doi.org/10.1076/call.11.3.309.5681

Ehrich, J. F., \& Dunstan, B. H. (2018). Rasch analysis of the metacognitive awareness listening questionnaire (MALQ), International Journal of Listening, 33(02), 113. https://doi.org/10.1080/10904018.2017.1418350

Fahim, M., \& Fakhri Alamdari, E. (2014). Exploring the effect of the model of metacognitive instruction on the listening performance of EFL learners. International Journal of Research Studies in Language Learning, 3(3), 79-91. https://doi.org/ 10.5861/ijrsll.2014.700

Field, J. (2008). Listening in the language classroom. Cambridge University Press.

Fuente, M. J. (2014). Learners' attention to input during focus on form listening tasks: The role of mobile technology in the second language classroom. Computer Assisted Language Learning, 27(3), 261-276. https://doi.org/10.1080/09588221.2012.733710

Hulstijn, J. H. (2003). Connectionist models of language processing and the training of listening skills with the aid of multimedia software. Computer Assisted Language Learning, 16, 413-425. https://doi.org/10.1076/call.16.5.413.29488

Hwang, W. Y., Huang, Y. M., Shadiev, R., Wu, S. Y., \& Chen, S. L. (2014). Effects of using mobile devices on English listening diversity and speaking for EFL elementary students. Australasian Journal of Educational Technology, 30(5), 503-516. https://doi.org/10.14742/ajet.237 
Johnson, R. E. (1970). Recall of prose as a function of the structural importance of the linguistic units. Journal of Verbal Learning and Verbal Behavior, 9, 12-20. https://psycnet.apa.org/doi/10.1016/S0022-5371(70)80003-2

Jones, L. (2002). Using technology in language teaching and listening comprehension: Revisiting what teachers should know and do. IALLT Journal of Language Learning Technologies, 34(2), 25-53. https://journals.ku.edu/IALLT/article/download/8360/7875/

Kukulska-Hulme, A., \& Bull, S. (2009). Theory-based support for mobile language learning: Noticing and recording. International Journal of Interactive Mobile Technologies, 3(2), 12-18. https://doi.org/10.3991/ijim.v3i2.740

Lai, C., \& Gu, M. (2011). Self-regulated out-of-class language learning with technology. Computer Assisted Language Learning, 21(4), 317-335. http://dx.doi.org/10.1080/09588221.2011.568417

Laufer, B., \& Hill, M. (2000). What lexical information do L2 learners select in a CALL dictionary and how does it affect word retention? Language Learning and Technology, 3(2), 58-76. http://dx.doi.org/10125/25073

Lavine, R. (1992). Rediscovering the audio language laboratory: Learning through communicative tasks. Hispania, 75(5), 1360-1367. https://doi.org/10.2307/344408

Li, W. (2013). A study of metacognitive awareness of non-English majors in L2 Listening. Journal of Language Teaching and Research, 4(3), 504-510. https://doi.org/10.4304/jltr.4.3.504-510

Luzon, M., J., \& Gonzalez, M. I. (2006). Using the Internet to promote autonomous learning 12 in ESP. In E. Arno, A. Soler, \& C. Rueda (Eds.), Information Technologies in Language for specific purposes, issues and prospects, (pp. 177-190). Springer. https://doi.org/10.1007/978-0-387-28624-2

Matthews, J., \& O'Toole, J. M. (2013). Investigating an innovative computer application to improve L2 word recognition from speech. Computer Assisted Language Learning, 28(4), 1-19. https://doi.org/10.1080/09588221.2013.864315

Nation, I. S. P. (2001). Learning vocabulary in another language. Cambridge: Cambridge University Press. https://doi.org/10.1017/CBO9781139858656

Ngo, N. T. H. (2015). Some insights into listening strategies of learners of English as a foreign language in Vietnam. Language, Culture and Curriculum, 28(3), 311326. https://doi.org/10.1080/07908318.2015.1080721

Oberg, A., \& Daniels, P. (2013). Analysis of the effect a student-centered mobile learning instructional method has on language acquisition. Computer Assisted Language Learning, 26(2), 1-20. https://doi.org/10.1080/09588221.2011.649484

Palalas, A. (2011). Mobile-assisted language learning: Designing for your students. In S. Thouësny \& L. Bradley (Eds.), Second language teaching and learning with technology: Views of emergent researchers (pp. 71-94). Researchpublishing.net. https://files.eric.ed.gov/fulltext/ED574599.pdf

Pardo- Ballester, C. (2012). CALL evaluation: Students' perception and use of LoMásTv. CALICO Journal, 29(3), 532-547. https://doi.org/ $10.11139 /$ cj.29.3.532-547 
Plass, J. L., \& Jones, L. C. (2005). Multimedia learning in second language acquisition. In R. E. Mayer (Ed.), The Cambridge handbook of multimedia learning (pp. 467-488). Cambridge University Press. https://psycnet.apa.org/doi/10.1017/CBO9780511816819.030

Plass, J. L., Chun, D. M., Mayer, R. E., \& Leutner, D. (1998). Supporting visual and verbal learning preferences in a second-language multimedia learning environment. Journal of Educational Psychology, 90(1), 25-36. https://psycnet.apa.org/doi/10.1037/0022-0663.90.1.25

Pujolà, J. T. (2002). CALLing for help: Researching language learning strategies using help facilities in a web-based multimedia program. ReCALL, 14(2), 235-262. https://doi.org/10.1017/S0958344002000423

Rahimi M., \& Katal M. (2012). The role of metacognitive listening strategies awareness and podcast-use readiness in using podcasting for learning English as a foreign language. Computers in Human Behavior, 28(4), 1153-1161. https://doi.org/ http://dx.doi.org/10.1016/j.chb.2012.01.025

Read, T., Kukulska-Hulme, A., \& Barcena, E. (2021). Supporting listening comprehension by social network-based interaction in mobile assisted language learning. Porta Linguarum, 35, 295-309. https://doi.org/10.30827/portalin.v0i35.15341

Read, T., \& Barcena, E. (2016). Metacognition as scaffolding for the development of listening comprehension in a social MALL App. RIED, 19(1), 103-120. https://doi.org/10.5944/ried.19.1.14835

Rivens-Mompean, A., \& Guichon, N. (2009). Assessing the use of aids for a computermediated task: Taking notes while listening. JALT CALL Journal 5(2), 45-60. https://doi.org/10.29140/jaltcall.v5n2.79

Robin, R. (2007). Learner-based listening and technological authenticity. Language Learning and Technology, 11, 109-115. http://dx.doi.org/10125/44092

Rost, M. (1994). Introducing listening. Penguin Group.

Rost, M. (2011). Teaching and researching listening ( $2^{\text {nd }}$ ed.). Pearson.

Roussel, S. (2011). A computer assisted method to track listening strategies in second language learning. ReCALL, 23(2), 98-116. https://doi.org/10.1017/S0958344011000036

Roussel, S., \& Tricot, A. (2012). A tentative approach to analysing listening strategies in CALL. Social and Behavioral Sciences Procedia Social and Behavioral Sciences, 34, 193-197. https://doi.org/ 10.1016/j.sbspro.2012.02.038

Scheiter, K., \& Gerjets, P. (2007). Learner control in hypermedia environments. Educational Psychology Review, 19, 285-307. https://psycnet.apa.org/doi/10.1007/s10648-007-9046-3

Stockwell, G. (2008). Investigating learner preparedness for and usage patterns of mobile learning. ReCALL, 20(3), 253-270. https://doi.org/10.1017/S0958344008000232

Stockwell, G. (2013). Tracking learner usage of mobile phones for language learning outside of the classroom. CALICO Journal, 118-136. https://journal.equinoxpub.com/Calico/article/view/7922 
Tavakoli, M., Shahraki, S., \& Rezazadeh, M. (2012). The relationship between metacognitive awareness and EFL listening performance: focusing on IELTS higher and lower scorers. The Journal of Language Teaching and Learning, 2, 24-37. https://arastirmax.com/en/system/files/dergiler/20415/makaleler/2/2/ arastirmax-relationship-between-metacognitive-awareness-and-efl-listeningperformance-focusing-ielts-higher-and-lower-scorers_0.pdf

Toapanta Túarez, J. L. T. (2018). Metacognitive instruction in L2 listening: An intervention study. Unpublisheddoctoral dissertation. University of Alberta, Alberta, Canada. https://era.library.ualberta.ca/items/a7f0bfc8-90b4-4d0dbadd-fc4e69ae537a

van Zeeland, H., \& Schmitt, N. (2013). Incidental vocabulary acquisition through L2 listening: A dimensions approach. System, 41(3), 609-624. http://dx.doi.org/10.1016/j.system.2013.07.012

Vandergrift, L. (1998). Successful and less successful learners in French: What are the strategy differences? The French Review, 71(3), 370-395.

Vandergrift, L. (2004). Listening to learn or learning to listen. Annual Review of Applied Linguistics, 24, 3-25

Vandergrift, L. (2007). Recent developments in second and foreign language listening. Language Teaching, 40, 191-210. https://doi.org/10.1017/S0261444807004338

Vandergrift, L., \& Goh, C. (2012). Teaching and learning second language listening: Metacognition in action. Routledge.

Vandergrift, L., Goh, C., Mareschal, C., \& Tafaghodtari, M. H. (2006). The metacognitive awareness listening questionnaire (MALQ): Development and validation. Language Learning, 56, 431-462. https://doi.org/10.4324/9780203843376

Vidal, K. (2011). A comparison of the effects of reading and listening on incidental vocabulary acquisition. Language Learning, 61, 219-258. https://doi.org/10.1111/j.1467-9922.2010.00593.x

Vogely, A. J. (1995). Perceived strategy use during performance on three authentic listening comprehension tasks. The Modern Language Journal, 79, 41-56. https://doi.org/10.1111/j.1540-4781.1995.tb05414.x

Waring, R., \& Takaki, M. (2003). At what rate do learners learn and retain new vocabulary from reading a graded reader? Reading in a Foreign Language, 15(2), 130-163. https://www.nflrc.hawaii.edu/rfl/October2003/waring/waring.html

Yeldham, M., \& Gruba, P. (2016). The development of individual learners in an L2 listening strategies course. Language Teaching Research, 20(1), 9-34. https://doi.org/10.1177\%2F1362168814541723

Zhao, Y. (1997). The effects of listeners' control of speech rate on second language comprehension. Applied Linguistics, 18(1), 49-68. https://doi.org/10.1093/applin/18.1.49

Zou, B. (2013). Teachers' support in using computers for developing students' listening and speaking skills in pre-sessional English courses. Computer Assisted Language Learning, 26(1), 83-99. https://doi.org/10.1080/09588221.2011.631143 


\section{İkinci Dilde Özdenetimli Mobil Dinleme Ortamında Navigasyon Stratejileri ve Üstbilişsel Farkındalık}

\section{$\ddot{O} \mathbf{z}$}

Bu çalışma, özdenetimli bir mobil öğrenme ortamında, ikinci dil öğrenenlerin dinleme sırasında kullandıklar navigasyon stratejilerini ve mobil destekli dinlemeye ilișkin üstbilişsel farkındalı̆̆ın dinlediğini hatırlama, rastlantısal kelime ögrenimi ve dinleme süresi ile ilişkili olup olmadı̆̆ını araştırmayı amaçlamıştır. Ikkinci dil yeterliği düşük düzeyde olan ögrenciler iki deney grubuna rastgele atanmıștır: dinleme esnasında ses kontrol araçlarına erişimi olan deney grubu ve ses kontrol araçlarına erişimi olmayan grup. Her iki gruptaki katılımcılar Üstbilişsel Farkındalık Dinleme Anketini (MALQ) cevapladıktan sonra 13.56 dakikalık bir hikâyeyi cep telefonundan dinleyerek hatırladıklarını yazmaları istenmiş ve daha önce bilgilendirilmedikleri kelime testleri verilmiştir. Sonuçlar, dinleme sürecini kontrol etmelerine izin verilen deney grubundaki katılımclların ilk dinlemede global ve analitik dinleme stratejilerini esit olarak tercih ettiklerini, ikinci dinlemede ise analitik stratejiler kullanma ĕgiliminde olduklarını göstermiştir. Ayrıca, dinleme sürecini kontrol etmenin dinlediğini hatırlama ve rastlantısal kelime öğrenme açısından herhangi bir üstünlüğü gözlemlenmemiștir. Son olarak, ögrencilerin üstbilișsel strateji kullanımları ile dinlediğini hatırlama, tesadüf kelime öğrenme ve dinleme görevine harcadıkları zaman arasında farklı ilişki örüntüleri gözlemlenmiştir.

Anahtar sözcükler: İkinci dilde dinleme stratejileri, ikinci dilde mobil destekli dinleme, üstbilişsel farkındalık, ikinci dilde özdenetimli dinleme, rastlantısal kelime öğrenimi 